\title{
The Rate of Anterior Commissure Invasion in Supracricoid Laryngectomy
}

\author{
Suprakrikoid Larenjektomide Ön Komissür Invazyonu Oranı
}

\author{
Mehmet Akif Abakay', Selcuk Gunes², Ibrahim Sayin', Burak Olgun³, Basak Saygan Usta', Didem Canoglu4, \\ Mehmet Sar ${ }^{5}$, Duygu Yegul ${ }^{6}$ \\ ${ }^{1}$ Otorhinolaryngology Department, Bakirkoy Dr Sadi Konuk Research and Training Hospital, Health Science University; \\ ${ }^{2}$ Otorbinolaryngology Department, Memorial Hizmet Hospital; ${ }^{3}$ Otorbinolaryngology Department, ENT Hospital; ${ }^{4}$ Pathology \\ Department, Health Science University Kartal Lutfi Kirdar Research and Training Hospital; ${ }^{5}$ Pathology Department, Istanbul \\ University Cerrahpasa Medical Faculty; ${ }^{6}$ Radiodiagnostics Department, Bakirkoy Dr Sadi Konuk Research and Training Hospital, \\ Health Science University, Istanbul, Turkey
}

\begin{abstract}
Aim: To determine the pathologic anterior commissure invasion rate in patients undergoing supracricoid partial laryngectomy.

Material and Method: We have reviewed retrospectively the files of patients who underwent supracricoid partial laryngectomy for squamous cell carcinoma of the larynx in our clinic to determine the rates of pathologic anterior commissure invasion and to investigate the relationship of pathologic anterior commissure invasion according to other characteristics of the tumor.
\end{abstract}

Results: Anterior commissure invasion was found in $51.8 \%$ of the patients who underwent supracricoid partial laryngectomy. Some $64.3 \%$ of the patients with anterior commissure invasion were in stage T2. The anterior commissure invasion rate was $56.25 \%$ in T2 tumors. Anterior commissure invasion was detected in all patients with $T 1 \mathrm{~b}$, whereas no anterior commissure invasion was detected in any $T 3$ cases.

Conclusion: In the selection of the supracricoid laryngectomy technique, which can be performed effectively and safely in the treatment of glottic region tumors, anterior commissure invasion is critical, and T1b tumors, in particular, should be evaluated carefully for anterior commissure invasion.

Key words: glottic; larynx; cancer; invasion

\section{ÖZET}

Amaç: Suprakrioid parsiyel larenjektomi uygulanan hastalarda patolojik ön komissür invazyonu oranının belirlenmesi

Materyal ve Metot: Kliniğimizde larenksin skuamöz hücreli kanseri nedeniyle suprakrikoid larenjektomi uygulanmıș olan hastaların dosyalarındaki patolojik ön komissür invazyonu oranı ve patolojik ön komissür invazyonu ile tümörün diğer özellikleri retrospektif olarak tarandı.

Bulgular: Suprakrikoid parsiyel larenjektomi uygulanan hastalarda ön komissür invazyonu oranı \%51,8 olarak saptandı. Ön komissür invazyonu olan hastaların \%64,3'ü T2 evresinde idi. Fakat, T2 evresindeki hastaların \%56,25'inde ön komissür invazyonu tespit edildi. T3 evresindeki hastalarda ön komissür invazyonu tespit edilmemișken, T1b evresindeki hastaların tümünde ön komissür invazyonu tespit edildi.

Sonuç: Glottik bölge kanserlerin tedavisinde etkili ve güvenli bir metod olan suprakrikoid parsiyel larenjektomi kararı verilirken ön komissür invazyonu değerlendirilmesi kritiktir, ve T1b tümörlerde ön komissür invazyonu dikkatlice değerlendirilmelidir.

Anahtar kelimeler: glottis; larenks; kanser; invazyon

\section{Introduction}

The glottic region is the most common region for laryngeal carcinoma. Due to the increased chance of early diagnosis and poor lymphatic system, glottic carcinoma has a better prognosis than other laryngeal levels. Early-stage glottic laryngeal carcinoma is defined as tumor limited to the glottic region (T1) or invasion of one subsequent compartment of the larynx and/ or decreased vocal cord mobility (T2) without any

iletișim/Contact: Mehmet Akif Abakay, Health Science University Bakirkoy Dr Sadi Konuk Research and Training Hospital, Otorhinolaryngology Department, Istanbul, Turkey・Tel:05053860900 • E-mail:mehmetakif.abakay@saglik.gov.tr • Geliș/Received:22.10.2020 • Kabul/Accepted:3.02.2021

ORCID: Mehmet Akif Abakay, 0000-0003-0413-421X • Selçuk Güneş, 0000-0001-9458-5799 • İbrahim Sayın, 0000-0003-3388-7835 • Burak Olgun, 0000-0002-3117-5861 • Başak Saygan Usta, 0000-0002-8161-2679 • Didem Canoğlu, 0000-0002-8942-9174 • Mehmet Sar, 0000-0003-1445-6685 • Duygu Yegül, 0000-0002-0671-3058 
metastases. For a good prognosis, the treatment goal is to achieve the least morbidity with the greatest local control and survival rates with a single treatment modality.

Treatment modalities for early-stage laryngeal carcinoma consist of radiotherapy (RT), transoral microsurgery (TM), and open laryngectomies. Supracricoid laryngectomy (SCL) is one of the important open laryngectomy techniques, which can be considerable when AC involvement exists, and can also be used in T3 glottic or transglottic tumors ${ }^{1,2}$. SCL provides a functional respiratory tract without permanent tracheotomy and a digestive tract without permanent gastrostomy in selected cases with good survival rates ${ }^{1,3,4}$.

The anterior commissure (AC) is located between the vocal folds. Owing to its unique anatomic properties, AC involvement may ease thyroid cartilage invasion, spread to the pre-epiglottic area, and extralaryngeal spread via the cricothyroid membrane $e^{5}$ Open laryngectomies are usually performed when the AC is involved because survival rates decrease with RT and TM. Also, not all patients with AC involvement have thyroid cartilage invasion (TCI). Therefore, while considering the treatment modality, the AC must be evaluated carefully, although laryngoscopic evaluation may be difficult because of inadequate exposure ${ }^{1,6,7}$. Underevaluation may cause decreased survival, and over-consideration may cause increased morbidity. Due to its unique anatomic properties, in preoperative radiologic evaluation, neither computed tomography (CT) nor magnetic resonance imaging (MRI) provides reliable information about $\mathrm{TCI}^{8}$.

The aim of this study was to determine the ratio of pathologic anterior commissure invasion in patients undergoing SCL because of anterior commissure involvement, and the diagnostic accuracy of preoperative radiologic examinations.

\section{Material and Method}

Twenty-seven patients who underwent SCL between 2010 and 2018 in our clinic were included in the study. The patients' information was obtained retrospectively from files. Ethics approval was obtained from the hospital's ethics committee (Approval No: 2018-305).

Sex, age, type of reconstruction, preoperative treatment status, postoperative follow-up period, $\mathrm{T}$ and $\mathrm{N}$ stage, postoperative recurrence, death, number of preserved arytenoids, number of patients receiving postoperative RT, and the discharge time of patients were recorded. Afterwards, pathology specimens were reevaluated and the presence of anterior commissure invasion was reevaluated by a pathologist.

All patients were decannulated and fed orally before discharge, except those who were to receive RT. Indication for SCL. Whether the patients' tumors were suitable for SCL was decided in a preoperative flexible endoscopic evaluation, radiologic examination (CT, MRI), and direct laryngoscopy-biopsy performed under general anaesthesia. Patients who were accepted as candidates for surgery were evaluated for their neurologic and respiratory capacity. Patients with a forced expiratory volume in 1 second (FEV1) less than 60\%, neurodegenerative disease or cerebrovascular accident sequelae that affected swallowing function were not accepted as candidates for SCL. Age was not considered as a contraindication for SCL.

In addition to SCL, if a supraglottic tumor was present, bilateral functional neck dissection was performed, if advanced lateralized glottosubglottic or recurrent tumors after endolaryngeal cordectomy were present, unilateral neck dissection was performed. Neck dissection was not performed for isolated anterior commissure tumors.

Radiologically positive invasion criteria were accepted as more than $1 \mathrm{~mm}$ thickening at the anterior commissure location, in at least two consecutive axial images.

\section{Statistical Analysis}

Kaplan-Meier survival analysis was performed to investigate the relation of anterior commissure invasion, and $\mathrm{T}$ and $\mathrm{N}$ status with overall survival (OS). The Chi-square and Fisher's exact test were performed to analyze the relationship between anterior commissure invasion and $\mathrm{N}$ status, and also between radiologic imaging and pathologic invasion status. Descriptive analyses were also performed.

\section{Results}

Twenty-seven patients who underwent SCL between 2010 and 2018 in our hospital's otolaryngology clinic were included in the study. Three patients who underwent SCPL because of vocal cord fixation were excluded from the study. A total of 24 patients ( 21 males, 3 females) were included in the final analysis. 
The mean age of the patients was $57.7( \pm 7.76)$ years. The mean follow-up period was $23 \pm 17.42$ (range, 3-65) months. There were two (8.3\%) cases of recurrence and three (12.5\%) deaths during the follow-up period. One death was disease-related.

There were no significant relations between OS and $\mathrm{T}, \mathrm{N}$, thyroid cartilage invasion, and location in the univariate analysis. Also, there were no significant relations between TCI and T, N, recurrence, and exitus in the Fisher's exact test.

The radiologic imaging of $16(59 \%)$ patients was available for reinvestigation. Fifteen patients were evaluated with CT and one patient was evaluated through MRI. Eleven (68\%) patients were radiologically positive for anterior commissure invasion. Pathologic thyroid cartilage invasion was detected in eight (72.7\%) of the 11 patients with radiologic positivity, and one (20\%) patient who was negative radiologically showed thyroid cartilage invasion pathologically. The sensitivity was $88.8 \%$ and specificity was $57 \%$.

From the 15 patients who were preoperatively evaluated with CT, pathologic thyroid cartilage invasion was present in nine $(60 \%)$ patients, eight of whom were diagnosed as positive using CT. From six patients who were pathologic negative, the CT diagnosis was negative in four. The sensitivity was $88 \%$ and the specificity was $66 \%$, the positive predictive ratio was $80 \%$, and the negative predictive ratio was $80 \%$.

Eight (33.3\%) tumors were in the glottic region, six $(25 \%)$ were in the glottic+subglottic region, nine $(37.5 \%)$ were in the glottic+supraglottic region, and one (4.1\%) involved all three laryngeal areas.

Anterior commissure invasion was found at a rate of $58.3 \%$. The number of pathologic anterior commissure involvements according to tumor location is shown in Table 1.

The distribution of patients according to $\mathrm{T}$ stage is shown in Table 2.

When the patients were grouped according to T stage, it was seen that 16 patients $(66.6 \%)$ were in stage T2 and $64.3 \%$ of patients who had anterior commissure invasion were in stage T2. However, the anterior commissure invasion rate was $56.25 \%$ in T2 tumors. Four (16.6\%) stage T1a and four (16.6\%) stage T1b tumors were present. Three of the T2 tumors were glottic, six were glottic + subglottic, 10 were glottic + supraglottic, and two glottic + subglottic + supraglottic tumors.
In the present study, in the evaluation of the anterior commissure invasion performed according to the $\mathrm{T}$ stage, all four patients in stage T1b had anterior commissure invasion. Although SCL was performed because of tumor in the anterior commissure, pathologic anterior commissure invasion was detected in only one of the four T1a tumors.

In one patient, subglottic invasion from the anterior commissure was $1 \mathrm{~cm}$ at the anterior border. However, the resection of the patients was not extended to total laryngectomy owing to negative margins in frozen section examinations after resection. In total, four patients underwent arytenoid resection.

After surgery, three patients received adjuvant RT according to the decision of the postoperative tumor council. One of these patients received concomitant chemotherapy. The remaining 21 patients, who did not receive RT, were decannulated postoperatively and oral intake was started. None of the decannulated patients was discharged without oral intake. No patient remained due to permanent gastrostomy due to aspiration. The mean discharge time was 22.9 days. The decannulation rate was $87.5 \%$.

Table 1. Distribution of pathological anterior commissure invasion by tumor location

\begin{tabular}{|c|c|c|c|}
\hline Tumor location & $\begin{array}{c}\text { Anterior } \\
\text { commissure } \\
\text { invasion present }\end{array}$ & $\begin{array}{c}\text { Anterior } \\
\text { commissure } \\
\text { invasion absent }\end{array}$ & Total \\
\hline Glottic & $5(38.3 \%)$ & $3(27.2 \%)$ & $8(33.3 \%)$ \\
\hline Glottic+Subglottic & $3(23 \%)$ & $3(27.2 \%)$ & $6(25 \%)$ \\
\hline Glottic+Supraglottic & $4(31.7 \%)$ & $5(45.5 \%)$ & $9(37.5 \%)$ \\
\hline All three & $1(7 \%)$ & - & $1(4.2 \%)$ \\
\hline Total & $13(100 \%)$ & $11(100 \%)$ & $24(100 \%)$ \\
\hline
\end{tabular}

Table 2. The distribution of patients according to T stage

\begin{tabular}{lccc}
\hline T stage & $\begin{array}{c}\text { Anterior } \\
\text { commissure } \\
\text { invasion present }\end{array}$ & $\begin{array}{c}\text { Anterior } \\
\text { commissure } \\
\text { invasion absent }\end{array}$ & Total \\
\hline T1a & $1(7.1 \%)$ & $3(30 \%)$ & 4 \\
T1b & $4(28.6 \%)$ & 0 & 4 \\
T2 & $9(64.3 \%)$ & $7(70 \%)$ & 16 \\
& $14(100 \%)$ & $10(100 \%)$ & 24 \\
\hline
\end{tabular}




\section{Discussion}

The aim of this study was to determine the pathologic, clinical, and radiologic anterior commissure invasion of 27 patients who underwent SCPL. Twenty-six patients had clinical anterior commissure involvement according to an endoscopic examination and direct laryngoscopy, and one patient underwent SCPL as an alternative to total laryngectomy due to cord fixation. We obtained radiologic examination results of 16 of these patients. The anterior commissure was diagnosed as invaded radiologically in 11 of the 16 patients. We detected pathologic anterior commissure invasion in all patients with T1b disease and 63\% of our patients with T2 disease. Therefore, we thought that SPCL would be the appropriate treatment modality, especially in patients with $\mathrm{T} 1 \mathrm{~b}$ and $\mathrm{T} 2$ disease, if preoperative commissure invasion was suspected.

The anterior commissure is a vertical area at the midline of the fused thyroid cartilages, at the same height as the vocal folds, and horizontally between the vocal folds ${ }^{9}$. This area is void of vascular structures and there is no glandular tissue. The anterior commissure area is very close to the thyroid cartilage because there is no inner perichondrium, which makes this area more important ${ }^{5}$. Although some authors believe contrarily, most are in consensus that AC involvement has adverse features ${ }^{10-13}$.

AC involvement, especially in early-stage tumors, is very important in deciding the treatment method because it adversely affects both survival and local control in patients undergoing RT and endolaryngeal surgery ${ }^{14}$. For this reason, SCL is recommended for the treatment of patients with $\mathrm{AC}$ involvement ${ }^{11}$.

SCL has worse morbidity and worse voice quality in early-stage laryngeal cancer treatment compared with endolaryngeal surgery or primary $\mathrm{RT}^{7,14}$. Accordingly, the question as to how many patients really have TCI in postoperative pathology is raised. Many studies in the literature give TCI in these patients as around $20 \%$, meaning that $80 \%$ of patients undergo overtreatment surgery.

Diagnosis of AC involvement is very challenging in the pretreatment period. Naiboğlu et al. ${ }^{10}$ stated that preoperative clinical examination, CT, and perioperative examination had $60.87 \%, 43.48 \%$, and $82.61 \%$ sensitivity, and $83.33 \%, 83.33 \%$, and $79.17 \%$ specificity, respectively. Our results were similar to the literature. MRI is more sensitive than CT but less specific, causing overstaging 5 . Therefore, CT is still recommended as the first imaging modality in glottic tumors 5 . Clinical endoscopic evaluation was correct in $40.38 \%$ of cases that could not be seen during direct laryngoscopy ${ }^{10,15}$.

Prades et al $^{9}$. reported that AC carcinoma could spread to local lymph nodes via supraglottic or subglottic lymphatic systems; however, we found no correlation between lymphatic metastasis and TC invasion.

Most patients with pathologic TCI were those who had ACs with inferior expansion due to epiglottic petiole in both the literature and our study. Hartl et al. ${ }^{6}$ found that impaired vocal cord mobility might be a finding for cartilage invasion. In the study by Ulusan et al. ${ }^{1}$, it was found that tumors invading the AC transglottically had a higher rate of cartilage invasion compared with tumors limited to the glottis.

The most striking result of our study was the invasion of the AC in all T1b tumors. Although the rate of $\mathrm{AC}$ invasion of $\mathrm{T} 1 \mathrm{~b}$ tumors in the literature is about $5 \%{ }^{1}$, our results reveal that $\mathrm{T} 1 \mathrm{~b}$ tumors, which are thought to be treated with endolaryngeal surgery or RT, should be treated more carefully. However, because we only evaluated four patients with T1b disease, our results must be supported by larger series.

In patients with suspicion of $\mathrm{AC}$ involvement originating from the epiglottic petiole, because the rate of pathologic TCI is very high, SCL promises greater survival compared with endolaryngeal surgery and RT. Sava et al. ${ }^{16}$ stated that, in their early glottic carcinoma series, thyroid cartilage invasion was present in only $8.3 \%$ of patients who were treated with frontolateral laryngectomy due to clinical AC involvement.

Our study has a few limitations. First, our sample size is too small to generalize our statistical results. Second, because the study was conducted retrospectively, we were unable to reevaluate all of the patients' radiologic examinations.

\section{Acknowledgements}

We would like to thank Mr David F. Chapman for editing the English of this article.

The study was presented at the 39th Turkish National Otorhinolaryngology Head and Neck Surgery Congress. 


\section{References}

1. Ulusan M, Unsaler S, Basaran B, Yilmazbayhan D, Aslan I. The incidence of thyroid cartilage invasion through the anterior commissure in clinically early-staged laryngeal cancer. Eur Arch Otorhinolaryngol 2016;273:447-453.

2. Atallah I, Berta E, Coffre A, Villa J, Reyt E, Righini CA. Supracricoid partial laryngectomy with crico-hyoidoepiglottopexy for glottic carcinoma with anterior commissure involvement. Acta Otorhinolaryngologica Italica 2017;37:18894.

3. Bradley PJ, Rinaldo A, Suárez, Shaha AR, Leemans R, Langendijk JA et al. Primary treatment of the anterior vocal commissure squamous Carcinoma. Eur Arch Otorhinolaryngol(2006)263:879-888.

4. Majer EH, Rieder W. Technic of laryngectomy permitting the conservation of respiratory permeability (cricohyoidepexy) Ann Otolaryngol 1959;76:677-81.

5. Porras AE, Vilaseca GI, García TM, Durban RB, Pallas GV, Mestre MS et al. Early glottic tumours with anterior commissure involvement. Literature review and consensus document. Head and Neck and Skull Base Commission, SEORL-CCC. Tumores glóticos precoces con afectación de la comisura anterior. Revisión bibliográfica y documento de consenso. Comisión de cabeza y cuello y base de cráneo. SEORL-CCC. Acta Otorrinolaringol Esp 2020;71 Suppl 1:1-20.

6. Hartl DM, Landry G, Hans S, Marandas P, Casiraghi O, Janot $\mathrm{F}$ et al. Thyroid cartilage invasion in early-stage squamous cell carcinoma involving the anterior commissure. Head Neck 2012;34(10):1476-9.

7. Hendriskima M, Sjögren EV. Involvement of the anterior commissure in early glottis cancer (Tis-T2): A review of the literature. Cancers (Basel)2019;11(9):1234.

8. Foucher M, Barnoud R, Buiret G, Pignat JC, Poupart M. Preand post-therapeutic staging of laryngeal carcinoma involving anterior commissure: Review of 127 cases. ISRN Otolaryngol 2012;2012:363148.
9. Prades JM, Peoc'h M, Petcu C, Karkas A, Dumollard JM, Gavid $\mathrm{M}$. The anterior commissure of the human larynx revisited. Surg Radiol Anat 2017;39(8):871-876.

10. Naiboglu B, Kinis V, Toros SZ, Habeşoğlu TE, Deveci I, Surmeli $\mathrm{M}$ et al. Diagnosis of anterior commissure invasion in laryngeal cancer. Eur Arch Otorhinolaryngol 2010;267(4):551-5. Erratum in: Eur Arch Otorhinolaryngol 2013;270(8):2379.

11. Allegra E, Saita V, Azzolina A, Natale MD, Bianco MR, Moidca DM, et al. Impact of the anterior commissure involvement on the survival of early glottic cancer treated with cricohyoidoepiglottopexy: a retrospective study. Cancer Manag Res 2018;10:5553-5558.

12. Pescetto B, Gal J, Chamorey E, Dassonville O, Poissonnet G, Bozec A. Role of supracricoid partial laryngectomy with cricohyoidoepiglottopexy in glottic carcinoma with anterior commissure involvement. Eur Ann Otorhinolaryngol Head Neck Dis 2018;135(4):249-253.

13. Tulli M, Re M, Bondi S, Ferrante L, Dajko M, Giordano L et al. The prognostic value of anterior commissure involvement in T1 glottic cancer: A systematic review and meta-analysis. Laryngoscope 2020;130(8):1932-1940.

14. Schindler A, Pizzorni N, Mozzanica F, Fantini M, Ginocchio D, Bertolin A, Crosetti E, Succo G. Functional outcomes after supracricoid laryngectomy: what do we not know and what do we need to know? Eur Arch Otorhinolaryngol 2016;273(11):3459-3475.

15. Barbosa MM, Araújo VJ Jr, Boasquevisque E, Carvalho R, Romano S, Lima RA et al. Anterior vocal commissure invasion in laryngeal carcinoma diagnosis. Laryngoscope 2005;115(4):724-730.

16. Sava HW, Dedivitis RA, Gameiro GR, Pfuetzenreiter EG, de Almeida RC, Matos LL et al. Morphological evaluation of thyroid cartilage invasion in early glottic tumours involving the anterior commissure. ORL J Otorhinolaryngol Relat Spec 2018;80(5-6):259-270. 